\title{
Adenosine stress test in characterization of ischemic heart disease
}

\author{
Marko Boban*, \\ Damir Raljević, \\ Vesna Pehar Pejčinović, \\ Viktor Peršić
}

Thalassotherapia Opatija - Clinic for treatment, rehabilitation and prevention of cardiovascular disease, Opatija, Croatia
RECEIVED:

July 24, 2015

ACCEPTED:

September 17, 2015

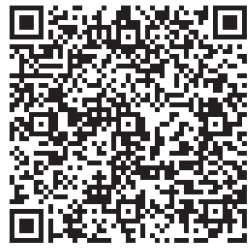

KEYWORDS: ischemic heart disease, adenosine stress test, cardiac magnetic resonance imaging CITATION: Cardiol Croat. 2015;10(9-10):213. | DOI: http://dx.doi.org/10.15836/ccar.2015.213

*ADDRESS FOR CORRESPONDENCE: Marko Boban, Thalassotherapia Opatija, M. Tita 188/1, HR-51410 Opatija, Croatia. Phone: +385-51-202-728 / E-mail: marcoboban@yahoo.com

ORCID: Viktor Peršić, http://orcid.org/0000-0003-4473-5431 • Damir Raljević, http://orcid.org/0000-0001-9743-9201 Vesna Pehar Pejčinović, http://orcid.org/0000-0002-8921-7999 • Marko Boban, http://orcid.org/0000-0002-6129-575X

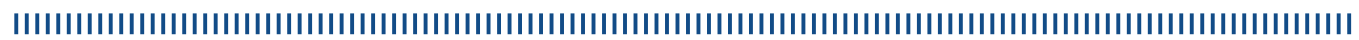

Ischemic heart disease is among most important constituents of cardiovascular disease continuum. The greatest proportion of total mortality burden in developed countries, as well as Croatia happens due to ischemic heart disease. On the other hand, a substantial part of the general population suffers of ischemic heart disease, experiencing among others lower social and professional level of activity, as well as lower quality of life. Cardiac magnetic resonance imaging (CMR) is becoming increasingly valuable as the diagnostic tool for making supplementary objective therapy guided decisions. Accessibility of CMR is in particular helpful for groups of patients with stable coronary disease, complex coronary lesions, earlier revascularizations, and others. Thanks to its favorable pharmacological characteristics, tolerance and safety profile adenosine stress test is the most commonly utilized form of stress-CMR in European Union. Adenosine-CMR stress test allows for quantification and characterization of perfusion defects, which offers important prognostic information, as well as improvement of quality of life, personalized risk assessment, and it can also be used as a screening tool.1-3

LITERATURE IIIIIIIIIIIIIIIIIIIIIIIIIIIIIIIIIIIIIIIIIIIIIIIIIIIIIIIIIIIIIIIIIIIIIIIIIIIIIIIIIIIIIIIIIIIIIIIIIIII

1. Kolh P, Windecker S, Alfonso F, Collet JP, Cremer J, Falk V, et. al. 2014 ESC/EACTS Guidelines on myocardial revascularization: the Task Force on Myocardial Revascularization of the European Society of Cardiology (ESC) and the European Association for Cardio-Thoracic Surgery (EACTS). Developed with the special contribution of the European Association of Percutaneous Cardiovascular Interventions (EAPCI). Eur J Cardiothorac Surg. 2014;46(4):517-92. DOI: http://dx.doi.org/10.1093/ejcts/ezu366

2. Montalescot G, Sechtem U, Achenbach S, Andreotti F, Arden C, Budaj A, et al. 2013 ESC quidelines on the management of stable coronary artery disease: the Task Force on the management of stable coronary artery disease of the European Society of Cardiology. Eur Heart J. 2013;34(38):2949-3003. DOI: http://dx.doi.org/10.1093/eurheartj/eht296

3. Silber S, Richartz BM. Evidence-based application of cardiac magnetic resonance and cardiac computed tomography for primary diagnosis of stable coronary artery disease with special attention to disease management programs and the German National Medical Care Guidelines. Herz. 2007;32(2):139-58. DOI: http://dx.doi.org/10.1007/s00059-007-2973-4 